\title{
Genealogical and genomic heritability for adaptability and reproductive traits in the Colombian Creole cattle breeds Blanco Orejinegro and Sanmartinero
}

\author{
C. De León ${ }^{1}$, R. Martínez ${ }^{2}$ and J.F. Rocha ${ }^{2}$ \\ ${ }^{1}$ Servicio Nacional de Aprendizaje SENA, Colombia \\ ${ }^{2}$ Corporación Colombiana de Investigación Agropecuaria-Agrosavia \\ Mosquera, Cundinamarca, Colombia \\ Corresponding author: C. De León \\ E-mail: crdeg@unal.edu.co
}

Genet. Mol. Res. 20 (3): gmr18878

Received April 13, 2021

Accepted June 20, 2021

Published July 31, 2021

DOI http://dx.doi.org/10.4238/gmr18878

\begin{abstract}
The Colombian Creole bovine breeds Blanco Orejinegro $(\mathrm{BON})$ and Sanmartinero (SM) are the most important of the Creole breeds in Colombia because they are the most numerous, the most widely used in their pure form or in crosses with foreign breeds, and because they are dual-purpose producers of milk and meat. We estimated heritability for adaptability (coefficient of adaptability-CA and heat tolerance coefficient-HTC), and reproductive traits (age at first calvingAFC and calving interval-CI) using genomic and genealogical records. Variance components were estimated using the AIREMLF90 program under a mixed single-trait model to calculate genealogical and genomic heritability, based on genealogical, phenotypic, and genomic information. Genomic information was obtained for 1,262 BON and 742 SM genotyped animals, with a total of 58,868 single nucleotide polymorphisms-SNPs in BON, and 57,482 SNPs in SM. Genealogical heritability values in BON for CA and HTC were 0.05 and 0.13 , and 0.06 and 0.13 for $\mathrm{AFC}$ and $\mathrm{CI}$, respectively. For the SM breed, genealogical heritability values for CA and HTC were 0.08 and 0.09 , and 0.20 and 0.07 for $\mathrm{AFC}$ and $\mathrm{CI}$, respectively. Genomic heritability values in the BON breed for CA and HTC were 0.06 and 0.16 , and 0.07 and 0.14 for $\mathrm{AFC}$ and $\mathrm{CI}$, respectively. For the SM breed, genomic heritability values for CA and HTC were 0.10 and 0.11 , and 0.20 and
\end{abstract}


0.07 for AFC and CI, respectively. Heritabilities for adaptability traits in both BON and SM were of medium to low magnitude, indicating the possibility of using these variables in selection schemes for adaptationrelated characteristics.

Key words: Adaptability; Cattle; Heritability; Reproductive traits

\section{INTRODUCTION}

Colombia has seven creole cattle breeds; of these, three are considered dual purpose, producing both milk and meat. They are Blanco Orejinegro (BON), Sanmartinero (SM), and Harton del Valle. Of these three breeds, BON and SM stand out for producing better-quality milk due to the higher milk fat content, total solids and protein. For this reason, they are the most commonly used breeds in crosses with foreign breeds not adapted to the climatic conditions of the Colombian tropics, such as Holstein, Swiss Brown, and Jersey. They are also very rustic breeds with good reproductive performance and resistance to diseases (Onofre et al., 2015).

The Iberian heat tolerance test or heat tolerance coefficient (HTC) proposed by Rhoad, (1944) and modified by Bianca (1963), and the Benezra test (1954) or coefficient of adaptability (CA), are indices extensively used to measure the degree of heat tolerance in cattle and other species living under stressful environmental conditions (Da Rocha et al., 2012; Da Silva et al., 2015; Seixas et al., 2017).

The HTC assesses heat tolerance by measuring rectal temperature (RT) when it exceeds the normal value of $38.3^{\circ} \mathrm{C}$. When the HTC value is 100 or close to 100 , the animal is more heat tolerant (Gaughan et al., 2012). According to Bianca, (1963), the HTC value decreases from 94 to 49 when environmental temperature increases from 30 to $50^{\circ} \mathrm{C}$. Similarly, HTC values from 89 to 90 were found by Rhoad (1944) in Brahman cows, and lower HTC values ranging from 75 to 87 were reported in Jersey cows by Gaughan et al. (2012).

The calculation of the coefficient of adaptability (CA) requires RT and respiratory rate (RR) data, because $R R$ is a mechanism used by animals to dissipate heat when suffering thermal stress (Gaughan et al., 2012). The CA assesses the degree of adaptability in adverse environmental situations (Gaughan et al., 2012), where a value of 2 or less than 2 indicates that the animal is highly adapted (Benezra, 1954). Because the CA and HTC values are influenced by environmental temperature (ET) and relative humidity $(\mathrm{RH})$, calculation of these indices entails the estimation of the temperature and humidity index (THI) during the same period of time CA and HTC are calculated (Gaughan et al., 2012).

The temperature and humidity index (THI) was proposed by Thom (1959) to measure the degree of "discomfort" in humans when the environmental temperature (ET) and the relative humidity (RH) are high. Since then, it has undergone several modifications for studying thermal stress in livestock. A THI of 74 indicates that the animal is in a comfortable state, while higher values indicate that the animal moves away from a comfortable zone and may suffer heat stress (Nienaber and Hanh, 2007).

Several Colombian cattle breeds show a better reproductive performance, with an earlier age at first calving (AFC), shorter calving intervals (CI) (Rocha et al., 2012), disease resistance and high heat tolerance (Rocha et al., 2019), attributes that make these animals an 
attractive genetic resource. A study performed in Colombian cattle showed a significant interaction between THI and breed, and between CA and breed on tick burden (Rocha et al., 2019). These authors found a higher tick burden when the CA was $>2$, while high THI values would be associated with a lower tick burden. Likewise, Bejarano et al. (2013) identified genomic regions with a significant effect on the CA and HTC in four Colombian Creole cattle breeds. Genomics has improved the accuracy of estimated breeding values in genetic evaluations, particularly in dairy cattle (Wiggans et al., 2011). Likewise, genomics, with the identification of molecular markers like SNPs, is particularly useful to identify genomic regions and genes that will be associated with the characteristics of interest. No studies have been carried out in these breeds to quantitatively estimate genetic parameters using genomic information. The aim of this work was to estimate heritability for CA, HTC, $\mathrm{AFC}$, and $\mathrm{CI}$ in $\mathrm{BON}$ and SM cattle using genomics information.

\section{MATERIAL AND METHODS}

The BON and SM breeds used in this study, belong to the Germplasm Bank of Corporación Colombiana de Investigación Agropecuaria (Agrosavia). BON animals are located in Antioquia, which is a state located in the Andean region of Colombia at $6^{\circ} 29^{\prime}$ $47^{\prime \prime}$ north latitude and $74^{\circ} 49^{\prime} 51^{\prime \prime}$ "west longitude and with latitudes ranging from 800 to 1,800 meters above the sea level (m.a.s.l). The topography is undulating with annual average temperatures between 18 and $24{ }^{\circ} \mathrm{C}$ and a bimodal rainfall pattern. SM animals are located in the Meta State in the Orinoquia region of Colombia at $4^{\circ} 3^{\prime} 27^{\prime}$ ' north latitude and $73^{\circ} 28^{\prime} 4^{\prime \prime}$ ' west longitude and with latitudes ranging from $336 \mathrm{~m}$ altitude in the humid tropical forest zone. There is a rainy season from April to November and a dry season from December to March, with annual average temperatures that range between 27 and $41{ }^{\circ} \mathrm{C}$, and relative humidity from 36 to $87 \%$. Both BON and SM populations were maintained under semi-extensive grazing conditions.

Research on animals was conducted according to the institutional committee on animal use.

Rectal temperature (RT) and respiratory rate (RR) data were included to estimate the adaptability indices (i.e., CA and HTC). The RT was measured using a veterinary digital thermometer, and the RR was measured by counting direct respiratory movements. These vital signs were measured between 12:00 p.m. to 3:30 p.m. for both breeds during the months of August to October corresponding to the rainy season. To estimate the heat tolerance coefficient, the following equation (Eq. 1) was used:

$$
H T C=100-[18 \times(R T-38.3)]
$$

where 100 is the maximum efficiency to maintain the temperature between the normal ranges; 18 is a constant, RT is the average rectal temperature recorded during the study, and 38.3 is the average rectal temperature of bovines (Bianca, 1963). The coefficient of adaptability (CA) was estimated employing the following equation (Eq. 2):

$$
C A=(R T / 38.33)+(R R / 23.0)
$$

where $\mathrm{RT}$ is the average rectal temperature recorded during the study, 38.33 is the average bovine temperature, $\mathrm{RR}$ is the respiratory rate recorded during the research, and 23.0 is the standard RR of bovines (Benezra, 1954). 
The temperature-humidity index (THI) was calculated employing environmental temperature (ET) and relative humidity $(\mathrm{RH})$ data that were recorded simultaneously when RT and RR were recorded for both breeds. The records of these environmental variables were taken from the meteorological databases of each research center (El Nus and La Libertad). ET and RH were recorded using ultra-light and small button-sized sensors called ibuttons that were located directly in the pastures where animals are usually herding and programmed to measure ET and RH every 15 minutes from 12:00 to 15:30.

A total number of 5,579 THI measurements were calculated in both breeds using the following equation (Eq. 3):

$$
T H I=1.8 x E T-(1-R H / 100) x(E T-14.3)+32
$$

where ET is the environmental temperature $\left({ }^{\circ} \mathrm{C}\right)$, and $\mathrm{RH}$ is the relative humidity $(\%)$ (Valtorta et al., 2000).

The genealogical and reproductive registers were collected between the years 1980 and 2017 in both research stations and were consolidated in the databases of the BON and SM germplasm banks. For this study, 1,927 AFC and 5,150 Calving Interval CI records were used. The genealogical information included a total of four to six generations of the populations analyzed.

Records from animals of a doubtful origin or with repeated identifications and with extreme or negative numbers were eliminated. In the BON breed, data with values ranging from 1.6 to 4.8 for CA, from 27.0 to 183.0 for HTC, from 775 to 1,306 days for AFC, and from 313 to 1,004 days for $\mathrm{CI}$ were included. For the SM breed, values ranging from 2.0 to 4.5 for CA, from 70 to 116 for HTC, from 667 to 1,501 days for AFC, and from 310 to 919 days for CI were included.

A total of 58,868 and 57,482 SNPs were included to calculate heritability in BON and SM, respectively. These SNPs come from 1,262 genotyped BON and 742 SM individuals (Table 1).

Table 1. Genotyped animals of the Colombian Creole breeds, Blanco Orejinegro (BON) and Sanmartinero (SM).

\begin{tabular}{llllr}
\hline Breed & 20KGeneSeek & BovineSNP50K & IlluminaSNP7K & Total \\
\hline BON & 490 & 643 & 129 & 1,262 \\
SM & 418 & 198 & 126 & 742 \\
\hline
\end{tabular}

Total Genotyped animal to breed BON, 1262 and to breed SM, 742, different types of chips were used for all animals, 7K (7000 SNPs), 20K (20000 SNPs) and 50K (50000 SNPs). Source: Agrosavia Genomics Laboratory.

SNPs and their genotypes obtained with the $7 \mathrm{~K}$ and $20 \mathrm{~K}$ chips were imputed to the $50 \mathrm{~K}$ chip using the Fimpiute program (Sargolzaei et al., 2014). After imputation, quality control (QC) was performed on 58,868 SNPs in BON and 54,782 in SM, using the BLUPF90 family programs. SNPs excluded from the analysis were those with a call rate lower than $90 \%$, SNP with a significant deviation from Hardy-Weinberg equilibrium ( $p$ $<0.01$ ) (e.g., a SNP in autosomal chromosomes presenting both homozygous genotypes but no heterozygotes), SNPs with an unknown genomic position, or those located in sex chromosomes. Moreover, monomorphic SNPs or with a minor allele frequency (MAF) below 0.03 were also excluded. Likewise, animals having a call rate lower than $90 \%$, 
with pedigree errors or Mendelian conflicts between relatives were excluded. After this, 51,283 effective polymorphic SNPs from autosomal chromosomes were obtained in BON, and 49,009 SNPs in SM. The genomic kinship matrix $(G)$ and its inverse $\left(G^{-1}\right)$ were generated using PREGF90. The numerator matrix from genotyped animals $\left(A_{22}\right)$, its inverse $\left(A^{-22}\right)$ and the $H$ matrix were created, integrating genomic and pedigree information. The whole quality control process was developed using these matrices and its inverse, plus the options within the program to estimate allelic frequencies (OPTION FreqFilev < file>) and chromosome mapping files (OPTION chrinfo < file>) (Misztal, 1998).

\section{Statistical Analysis}

Descriptive statistics, as well as genomic and genealogical heritability of adaptability indices and reproductive traits, were estimated in both breeds to establish the genetic contribution on the expression of each character. To calculate variance components, and from these, estimate heritability $\left(h^{2}\right)$, a uni-trait analysis was performed employing the AIREMLF90 program that belongs to the family of BLUPF90 programs, using a restricted maximum likelihood (REML) algorithm and applying a mixed animal model for each trait. Moreover, all fixed effects that were considered to have a significant effect on each variable in both breeds were included in the model. The fixed family effect (eight families in BON and 10 in SM) was incorporated in the four traits assessed. For CA and HTC, models included the month in which vital signs were recorded, the THI and the age of the cow as covariates. For AFC and CI, fixed effects such as year and month of calving were included. In the case of CI, the model included age at first calving and calving order. For traits that had more than one value in the same animal, i.e., CA, HTC, and CI, the effect of the permanent environment was not included, as it severely affected the adjustment of the model, causing changes in the values of additive variance to very high levels; this was evidenced in a previous analysis (data not included).

The mixed animal model (Eq. 4) used for the analysis was:

$$
y=X \beta+Z a+e
$$

Where:

$y=$ vector $n \times 1$ of trait observations.

$X=$ known incidence matrix $n x p$ that associates $\beta$ with $y$.

$\beta=$ vector $p \times 1$ of solutions for fixed family effects, month in which the vital signs were recorded, THI and the age of the animal as covariates for HTC and CA; vector $p \times 1$ of solutions for fixed family effects, year and month of calving for AFC; and vector $p \times 1$ of solutions for fixed family effects, age at birth and calving interval as covariates for CI.

$a=$ vector $n \times 1$ of solutions for genetic values.

$Z=$ random effects matrix that associates $a$ with $y$.

$e=$ vector $n \times 1$ of the peculiar random residual effect of the observations that are not explained by other parts of the model.

The equation of the mixed animal model for CA, HTC, and AFC traits used to calculate genealogical heritability was as follows (Eq. 5):

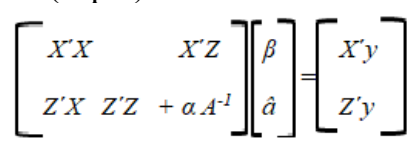

Where $A$ is the kinship matrix that includes all the animals in the population (bulls, fathers, mothers, grandparents, and collateral relatives); and $X$ and $Z$ are the incidence matrices. The 
term $\alpha$ is a scalar that relates the variance of the residue and the genetic variance as $\alpha=$ $\sigma 2 R / \sigma 2 A$ (Mrode and Thompson, 2014).

The equation of the mixed animal model for CA, HTC, AFC, and CI traits to calculate genomic heritability is the following (Eq. 6):

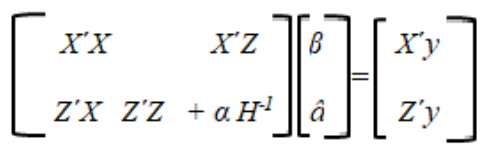

Where:

$H^{1}$ is the inverse of the $\mathrm{H}$ matrix that integrates matrices $A^{-1}$ and $G^{-1}$. Matrix A is a kinship or pedigree numerator matrix, and matrix $\mathrm{G}$ is a genomic kinship matrix constructed from the frequencies of the markers (Legarra et al., 2009); $X$ and $Z$ are the incidence matrices mentioned in the model. The term $\alpha$ is a scalar that relates the variance of the residual and the genetic variance, as $\alpha=\sigma 2 R / \sigma 2 A$ (Mrode and Thompson, 2014).

The equation for heritability $\left(h^{2}\right)$ from Falconer and McKay (2006) was implemented as follows (Eq. 7):

$$
h^{2}=\frac{\sigma^{2} A}{\sigma^{2} P}
$$

Where:

$\sigma^{2}$ is the direct genetic variance component.

$$
\sigma 2 P=\sigma 2 A+\sigma 2 R
$$

$\sigma_{P}^{2}$ is the phenotypic variance component derived from the observations.

$\sigma_{R}^{2}$ is the variance of residuals component.

\section{RESULTS}

Coefficient of adaptability (CA) and heat tolerance coefficient (HTC), means were $2.7 \pm$ 0.43 and $95.7 \pm 5.8$ in BON and 3.2 \pm 3.8 and 90.7 \pm 13.1 in SM, respectively. Moreover, Age at First Calving (AFC) and Calving Interval (CI) means were 1,086 \pm 54.5 days and $509.0 \pm 159.2$ days in BON, and 1,172 \pm 157.7 days and $467 \pm 135.2$ days in SM, respectively. The ranges for each of these traits are presented in Table 2.

\begin{tabular}{|c|c|c|c|c|c|c|}
\hline Indices & Breed & $\overline{\mathbf{Y}}$ & SD & Min & Max & Total \\
\hline \multirow{2}{*}{ Coefficient of adaptability } & BON & 2.7 & 0.43 & 1.6 & 4.8 & 1,742 \\
\hline & SM & 3.5 & 0.46 & 2.0 & 4.5 & 1,075 \\
\hline \multirow{2}{*}{ Heat tolerance coefficient } & BON & 95.7 & 5.8 & 27.0 & 183.0 & 1,742 \\
\hline & SM & 90.7 & 13.0 & 70.0 & $1,16.2$ & 1,072 \\
\hline \multirow{2}{*}{ Age at first calving } & $\mathrm{BON}$ & 1,086 & 54.5 & 775 & 1,301 & 958 \\
\hline & SM & 1,172 & 157.7 & 667 & 1,501 & 970 \\
\hline \multirow{2}{*}{ Calving interval } & $\mathrm{BON}$ & 509.0 & 159.5 & 313 & 1,004 & 2,293 \\
\hline & SM & 467.0 & 135.2 & 310 & 919 & 2,857 \\
\hline
\end{tabular}

Table 2. Mean, standard deviation, minimum and maximum values for adaptability indices and reproductive traits in the Colombian Creole breeds Blanco Orejinegro (BON) and Sanmartinero (SM). 


\section{Genealogical Heritability}

Results from genealogical heritability are shown in Table 3.

Table 3. Variance components, genealogical heritability, and standard deviation for adaptability indices and reproductive traits in the Colombian Creole cattle breeds, Blanco Orejinegro (BON) and Sanmartinero (SM).

\begin{tabular}{llcccc}
\hline Trait & Breed & $\begin{array}{l}\text { Additive genetic } \\
\text { variance }\end{array}$ & $\begin{array}{c}\text { Variance of } \\
\text { the residual }\end{array}$ & $\begin{array}{l}\text { Phenotypical } \\
\text { variance }\end{array}$ & Heritability \\
\hline \multirow{2}{*}{ CA } & BON & 0.010 & 0.157 & 0.167 & 0.05 \\
& SM & 0.019 & 0.20 & 0.219 & 0.08 \\
HTC & BON & 3.55 & 23.27 & 26.92 & 0.13 \\
& SM & 2.15 & 19.5 & 21.65 & 0.09 \\
AFC & BON & 865.6 & 12,324 & 13,189 & 0.06 \\
& SM & $4,016.3$ & 15,762 & $19,778.3$ & 0.20 \\
& BON & $3,675.3$ & 23,023 & $19,778.3$ & 0.13 \\
& SM & $1,174.8$ & 15,197 & $16,371.8$ & 0.07 \\
\hline
\end{tabular}

CA: Coefficient of adaptability; HTC: Heat tolerance coefficient; CI: Calving interval; AFC: Age at first calving. The genealogical heritabilities in BON were 0.05 for CA, 0.13 for HTC, 0.06 for AFC and 0.13 for CI. For SM, the heritabilities were 0.08 for CA, 0.09 for $\mathrm{HTC}, 0.20$ for AFC and 0.07 for CI.

\section{Genomic Heritability}

Results for genealogical heritability are shown in Table 4 .

Table 4. Variance components and genomic heritability for adaptability indices and reproductive traits in the Colombian Creole cattle breeds, Blanco Orejinegro (BON) and Sanmartinero (SM).

\begin{tabular}{|c|c|c|c|c|c|}
\hline Trait & Breed & $\begin{array}{l}\text { Additive genetic } \\
\text { variance }\end{array}$ & $\begin{array}{l}\text { Variance of the } \\
\text { residual }\end{array}$ & $\begin{array}{l}\text { Phenotypical } \\
\text { variance }\end{array}$ & Heritability \\
\hline \multirow{2}{*}{$\mathrm{CA}$} & $\mathrm{BON}$ & 0.011 & 0.156 & 0.167 & 0.06 \\
\hline & SM & 0.022 & 0.19 & 0.212 & 0.10 \\
\hline \multirow{2}{*}{ HTC } & $\mathrm{BON}$ & 4.54 & 22.38 & 26.92 & 0.16 \\
\hline & $\mathrm{SM}$ & 2.53 & 19.2 & 21.73 & 0.11 \\
\hline \multirow{2}{*}{$\mathrm{AFC}$} & $\mathrm{BON}$ & 939.9 & 12,261 & 13,200 & 0.07 \\
\hline & SM & $4,016.3$ & 15,762 & $19,778.3$ & 0.20 \\
\hline \multirow{2}{*}{ CI } & $\mathrm{BON}$ & 3,785 & 22,883 & 26,668 & 0.14 \\
\hline & SM & $51,174.8$ & 15,197 & 16,371 & 0.07 \\
\hline
\end{tabular}

\section{DISCUSSION}

BON showed a lower CA $(2.7 \pm 0.43)$ than $\mathrm{SM}(3.5 \pm 0.46)$, which indicates a better adaptation of BON to tropical conditions. Higher and similar $\mathrm{CA}$ values was observed by Espinoza et al. (2011) in cattle located in a dry subtropical zone. In that study, CA was 4.0 for Holstein, 3.9 for Jersey, 3.1 for Charolais x Brahman, and 3.0 for Mexican Creole cows. These differences might be explained by the conditions where they were kept, however, it is possible to hypothesize that breeds such as Holstein and Jersey would have in 
average a lower adaptability than BON and SM, even when they are also Bos taurus breeds, because of the shorter period of time they have been under tropical conditions in the Americas.

The higher HTC, found in BON $(95.7 \pm 5.8)$ compared to SM $(90.7 \pm 13.0)$ indicates a better heat tolerance level of the former breed. In a study of Bos indicus Red Sindhi heifers under semi-arid conditions (De Souza, et al., 2007) and using a scale from 0 to 10 (Baccari, 1986), an HTC of 9.83 was observed, indicating the high adaptability of this breed in harsh tropical climates. An HTC of 91 was found in Bos taurus $x$ Bos indicus cows under high temperature and humidity conditions (Da Rocha et al., 2012), which would indicate a similar adaptability to SM cattle but lower than BON. Both CA and HTC were significantly influenced by the family, month in which the vital signs were recorded, the THI and the age of the animal. The variance component of the permanent environment effect was excluded from these two traits because it severely affected the adjustment of the model, causing very high levels of additive variance.

Genomic heritabilities estimated for CA $(0.06$ and 0.10 for BON and SM, respectively) and $\mathrm{HTC}$ ( 0.16 and 0.11 for $\mathrm{BON}$ and $\mathrm{SM}$, respectively) were slightly higher than genealogical heritabilities (CA $=0.05$ and 0.08 for $\mathrm{BON}$ and $\mathrm{SM}$, respectively; $\mathrm{HTC}=$ 0.13 and 0.09 for BON and SM, respectively). On the other hand, the h2 for HTC was higher than the $\mathrm{h} 2$ for $\mathrm{CA}$ in both breeds, which indicates a higher influence of the environment and a lower genetic control on CA. Similar results were obtained by Bejarano et al. (2013) in Colombian cattle breeds, with genomic heritabilities of 0.08 for CA and 0.09 for HTC, and a considerable variation among breeds, being SM a breed with a lower genetic control on HTC than BON.

Some studies have estimated heritabilities not directly for adaptation indices such as CA and HTC but for components of them. In dairy production systems, a genealogical $\mathrm{h}^{2}$ of 0.17 and 0.31 was found for RT in Holstein and Jersey cattle, respectively (Dikmen et al., 2012). These are considered low to intermediate values of heritability, which means that the variability of temperature among individuals has an important genetic control in these populations. In a study made in crossbred New Zealand dairy cows, Morris et al. (2012) estimated $a n h^{2}$ of 0.19 for RT. Nonetheless, this value did not vary between both winter and summer seasons, which shows that this parameter is not affected by changes in the environmental temperature or other climatic conditions that are present during a particular season. This agrees with the idea that heat tolerance is an inheritable trait, and that selection can be used to increase its genetic gain in cattle populations.

Heat tolerance is determined by two important phenotypes, body temperature and respiratory rate, which have $\mathrm{h}^{2}$ values that range from 0.11 to 0.68 and from 0.76 up to 0.84 , respectively (Rolf, 2015), which indicates these traits are somewhat influenced by the environment but most of its variation is determined by genetics. The effect of genotypes associated with heat tolerance was showed by Garner et al. (2016) in Australian Holstein cattle under adverse climatic conditions. Those animals with heat tolerant genotypes, determined by rectal and intravaginal temperature and RR phenotypes during heat stress-, had a lower decrease in milk production compared with those that had a genotype associated with susceptibility to heat stress.

Martínez et al. (2013) studied the adaptability processes of the BON breed in a study of genetic variability using microsatellites, through the calculation of the $F_{S T}$ fixation index, which measures the amount of genetic variance explained by the structure of the 
population. The studied markers presented a high degree of polymorphism (171 alleles in 12 microsatellites) with a high degree of heterozygosity (0.73), which explains the promotion of genetic variability in the selection and adaptation processes.

Apart from traits that estimate the tolerance to heat stress, adaptability of cattle can also be measured by its the reproductive performance. In this study, BON showed a lower $\operatorname{AFC}(1,086 \pm 54.5 \mathrm{~d})$ than $\operatorname{SM}(1,172 \pm 157.7 \mathrm{~d})$, indicating an earlier sexual maturity in the former. A similar AFC in BON (1,104 d) was observed in a previous study (Rocha et al., 2012), while this parameter varied considerably (985 - 1,293 d) in other studies for SM (Correal and Henao, 2000; Ossa et al., 2007; Martínez-Villate et al., 2009). Lower AFC values have been found in Costa Rican (921 d) (Salazar et al., 2013), American (777 d) (Pirlo et al., 2000) and Korean Holstein cattle (730 - 790 d) (Do et al., 2013). In crossbred Colombian Angus x Brahman cows, Vergara et al. (2015) observed an AFC of 1,155 \pm 6.0 days. The CI observed for BON and SM in the present study $(509.0 \pm 159.5 \mathrm{~d}$ and $467.0 \pm$ $135.2 \mathrm{~d}$, respectively) is higher than the one found by Rocha et al. (2012) and MartínezVillate et al. (2009) for BON (487 $\pm 147 \mathrm{~d})$ and SM (439.42 $\pm 92.24 \mathrm{~d})$, respectively. Other studies have shown a CI that ranged from 366 to $472 \mathrm{~d}$ in purebred BON (Gutiérrez, 2003) and $544 \pm 97 \mathrm{~d}$ in crossbred BON x Cebu and BON x Angus x Cebu cattle (Vergara et al., 2008). In SM and Romosinuano, CI values of $492 \mathrm{~d}$ and $433 \pm 139 \mathrm{~d}$ have been reported, respectively (Correal and Henao, 2000; Ossa et al., 2007). Differences found for AFC and $\mathrm{CI}$ among studies might be attributed to different environment conditions, including health status, reproductive and nutritional management, however, it is also affected by the breed and therefore by genetics.

Genealogical heritabilities for $\mathrm{AFC}$ and $\mathrm{CI}$ in $\mathrm{BON}$ ( 0.06 and 0.13 , respectively) and SM ( 0.20 and 0.07 , respectively) were very similar to those estimated using genomic data $(\mathrm{AFC}=0.07$ and 0.20 in $\mathrm{BON}$ and $\mathrm{SM}$, respectively; $\mathrm{CI}=0.14$ and 0.07 in $\mathrm{BON}$ and $\mathrm{SM}$, respectively). Higher heritabilities for AFC (0.15) have been observed in purebred BON and crossbreds with Angus and Cebu (Vergara et al., 2008; Rocha et al., 2012). Likewise, $h^{2}$ values of 0.34 for AFC have been estimated in SM using genealogical data (Martínez-Villate et al., 2009), which is superior to $h^{2}$ values obtained in other breeds such as Holstein (0.11) and Nellore (0.21) (Azevedo et al., 2006; Do et al., 2013). This variation might be due to differences in the environment conditions where the animals were kept.

The heritability observed for AFC in SM and CI in BON indicates that selection for these traits would have an acceptable response in this population. This is not the case for traits with low $h^{2}$ values such as that estimated for AFC in the Boran $(0.04)$ (Wasike et al., 2009) and Nellore cattle (0.02-0-06) (Forni and Albuquerque, 2005; Grossi et al., 2009). The low heritabilities in some of these studies might be explained by the reproductive management, e.g., a late onset of the mating season which would affect the likelihood to get heifers pregnant at an early age, preventing them from expressing their genetic potential for sexual precocity.

Van der Westhuizen et al. (2001) found very low $h^{2}$ values for CI $(0.01)$ in multiracial African beef cattle. Likewise, Yagüe et al. (2009) observed a value of 0.08 in Rubia Gallega beef cattle. Some studies have even found $h^{2}$ values of zero for CI in Boran cattle (Wasike et al., 2009). This suggests a strong environmental effect on the expression of this trait, and a very low additive genetic influence. Very low heritabilities make the implementation of breeding programs difficult by slowing down the rate of genetic gain, therefore, selection would not have an optimum response. In these cases, control of the 
environment, reproductive management, nutrition and health status and implementation of crossbreeding to exploit the non-additive effects would be alternatives to improve adaptability in these cattle populations.

De Leon et al. (2019) conducted a GWAS genomic association study using SNPs in the BON and Sanmartinero breeds who identified 25 genomic regions in BON and 11 in SM associated with the traits evaluated in the present study, as well as genes involved in the physiological response to heat stress (RPTOR, TM2D1, RAB21 and ACOT13) and reproductive performance (SLC6A16, TMEM50A, NLRP9, KHDRBS2 and UBE2C).

\section{CONCLUSION}

From comparative statistical analysis between genealogical and genomic heritability, it can be concluded that the four characteristics studied presented a slight increase in the values of genomic heritability. Regarding the coefficients of tolerance to environmental stress, the Blanco Orejinegro breed (BON) increased its adaptability coefficient (CA) from 0.05 of its genealogical heritability to 0.06 in its genomic heritability and from 0.08 to 0.10 in the Sanmartinero breed, indicating that by including SNPs in the analysis, the influence of genes on the expression of this characteristic is better explained than including only the relatives of 6 previous generations of the animals analyzed. The heat tolerance coefficient (HTC) presented the same behavior, increasing from 0.13 to 0.16 in the BON breed and from 0.09 to 0.11 in the SM breed, from which we can conclude that the BON breed has a greater influence of certain genes on stress tolerance environmental for both characteristics. Regarding reproductive traits, age at first calving (AFC), increased from 0.06 to 0.07 in the BON breed and remained at 0.20 in the SM breed, indicating little or no difference between two heritabilities. However, value of genealogical and genomic heritability of 0.20 in the SM breed in contrast to the genomic heritability of 0.07 in the BON breed, explains that SM breed has best genetic influence in the females to have the same AFC than the BON breed. Genomic heritability from calving interval (CI) of 0.14 for the $\mathrm{BON}$ breed and 0.07 for the SM breed indicates that BON breed has better reproductive performance because it presents shorter calving intervals and therefore will present a greater number of offspring than the SM breed.

The heritability of adaptability and reproductive traits found in Colombian cattle was low to moderate, indicating an existing direct additive genetic influence on the variability for some of these traits that can be considered to exploit by selection in a breeding program along with the implementation of several herd management strategies.

\section{ACKNOWLEDGMENTS}

This Research was supported by the Ministerio de Agricultura y Desarrollo Rural under Agreement 1936 TV19 of 2019. We thank all the stockbreeders of BON and SM who provided the samples necessary to carry out this study.

\section{CONFLICTS OF INTEREST}

The authors declare no conflict of interest. 


\section{REFERENCES}

Azevêdo DM, Martins FR, Lôbo RN, Malhado CM, et al. (2006). Desempenho reprodutivo de vacas Nelore no Norte e Nordeste do Brasil. Rev. Bras. Zootec. 35: 988-996.

Baccari Jr F, Polastre R, Fré CA and Assis PS (1986). Um novo índice de tolerância ao calor para bubalinos: correlação com o ganho de peso. Reun. Anual da Socied. de Zootec. 23: 316.

Bejarano GDH, Martínez SRA, Cardozo CJ, Lucero EC, et al. (2013). Caracterización fisiológica y genética para atributos de adaptación a estrés ambiental en cuatro razas criollas colombianas. Revista Nacional de Ciencias Pecuarias, suplemento. Memorias XII Encuentro Nacional y V Internacional de los Investigadores de las Ciencias Pecuarias ENCIP. 26: 2256-2958.

Benezra MV (1954). A new index for measuring the adaptability of cattle to tropical conditions. Animal Sci. 13: 10151015.

Bianca W (1963). Rectal temperature and respiratory rate as indicators of heat tolerance in cattle. Agricultural Sci. 60: 113-120.

Correal GM and Henao FG (2000). El ganado criollo Sanmartinero (SM) y su potencial productivo. Animal Genet. Res. 28: 17.

Da Rocha RD; Flores SMG and Noronha A (2012). Índices de tolerância ao calor de vacas leiteiras no período chuvoso e seco no Ceará. Ciênc. Anim. 10: 335-343.

Da Silva PJP, De Souza BB, Da Assis SG, Pereira BF, et al. (2015). Analise do Coeficiente de Tolerancia ao Calor de Ovinos Mestiços $1 / 2$ Dorper $+1 / 2$ Santa Inés Suplementados Com Diferentes Niveis de Ionoforo no Semiárido da Paraiba. Rev. Cien. Prod. Anim 17: 30-36.

De Leon C, Manrique C, Martínez R and Rocha JF (2019). Genomic association study for adaptability traits in four Colombian cattle breeds. Genet. Mol. Res. 18(3): GMR18373. https://doi.org/10.4238/gmr18373.

De Souza BB, Da Silva NRM, Loureiro MM, De Assis SG, et al. (2007). Parâmetros fisiológicos e índice de tolerância ao calor de bovinos da raça sindi no semi-árido paraibano. Ciênc. Agrotec. 31: 883-888.

Dikmen S, Cole BJ, Null JD and Hansen JP (2012). Heritability of rectal temperature and genetic correlations with production and reproduction traits in dairy cattle. Dairy Sci. 95: 3401-3405.

Do Ch, Wasana N, Cho K, Choi Y, et al. (2013). The Effects of Age at First Calving and Calving Interval on productive Life and Lifetime Profit in Korean Holstein. Asian Austral. J. Anim. Sci. 26: 1511.

Espinoza JV, Ortega RP, Palacios AE and Guillen AT (2011). Tolerancia al calor y humedad atmosférica de diferentes grupos raciales de ganado bovino en La Paz, México. Rev. MVZ Córdoba. 16: 2302-2309.

Falconer DS and Mackay TF (2006). Introducción a la genética cuantitativa. Zaragoza, España: Editorial Acribia.

Forni S and Albuquerque LG (2005). Estimates of genetic correlations between days to calving and reproductive and weight traits in Nelore cattle. Animal Sci. 83: 1511-1515.

Gaughan JB, Mader TL and Gebremedhin KG (2012). Rethinking Heat Index Tools for Livestock. Environmental physiology of Livestock. 243-63.

Garner JB, Douglas ML, Williams SRO, Wales WJ, et al. (2016). Genomic Selection Improves Heat Tolerance in Dairy Cattle. Sci. Rep. 6: 34114.

Grossi DA, Venturini G, Paz CC, Bezerra LA, et al. (2009). Genetic associations between age at first calving and heifer body weight and scrotal circumference in Nelore cattle. Anim. Breed. Genets. 126: 387-393.

Gutiérrez ID (2003). Ganado criollo Blanco Orejinegro. Razas criollas y colombianas puras. Colombia. MADRAsocriollo. p. 58-73.

Legarra A, Aguilar I and Misztal I (2009). A relationship matrix including full pedigree and genomic information. Dairy Sci. 92: 4656-4663. doi: 10.3168/jds.2009-2061.

Martínez R, Llinás AP and Rocha JF (2013). Genetic variability in Blanco Orejinegro breed cattle populations in Colombia. Genet. Mol. Res. 12: 1083-1094. doi http://dx.doi.org/10.4238/2013.

Martínez-Villate GC, Martínez G and Manrique C (2009). Estimación de parámetros genéticos de edad al primer parto e intervalo entre partos de vacas criollas Sanmartineras. Orinoquia. 13: 113-125.

Misztal I (1998). BLUPF90. A flexible mixed model program in Fortran 90. Georgia University. 1-24.

Morris CA, Jones KR and Wilson JA (2012). Heritability of rectal temperature and relationship with growth in young cattle in a temperate climate. New Zealand J. Agric. Res. 32: 375-378.

Mrode RA and Thompson R (2014). Linear Model for the Prediction of Animal Breeding Value. CABI. $3^{\text {rd }}$ Edition. Editorial Gutenberg, Malta.

Nienaber A and Hanh G (2007). Livestock Production System Management responses to thermal challenges. Int. J. Biometeorol. 52: 149-157

Onofre G, Parra J, Martínez R, Cassalett E, et al. (2015). Productive potential and milk quality of native cattle breedsBlanco Orejinegro, Harton del Valle and Sanmartinero in the Piedmont plains of Colombia. AICA. 5: 15-17.

Ossa GA, Suárez MA and Pérez JE (2007). Factores ambientales y genéticos que influyen la edad al primer parto y el intervalo entre partos en hembras de la raza criolla Romosinuano. Cienc. Tec. Agro. 8: 74-80. 
Pirlo G, Miglior F and Speroni M (2000). Effect of age at first calving on production traits and on difference between milk yield returns and rearing costs on Italian Holsteins. Dairy Sci. 83: 603-608.

Rocha JF, Gallego JL, Vásquez RF, Pedraza JA, et al. (2012). Estimation of genetic parameters for age at first calving and calving interval in Blanco Orejinegro (BON) breed cattle populations in Colombia. Colombiana de Ciencias Pecuarias. 25: 220-228

Rocha JF, Martínez R, Morris ST and Lopez-Villalobos N (2019). Tick burden in Bos taurus cattle and its relationship with heat stress in three agroecological zones in the tropics of Colombia. Parasit. Vectors 12: 73.

Rhoad AO (1944). The Iberian heat tolerance test for cattle. Trop. Agric. 21: 162-164.

Rolf MM (2015). Genetic Basis for Heat Tolerance in Cattle. Oklahoma University.

Salazar CM, Castillo BG, Murillo HJ, Hueckmann VF, et al. (2013). Edad al primer parto en vacas Holstein de lechería especializada en Costa Rica. Agro. Meso. 24: 233-243.

Sargolzaei M, Chesnais JP and Schenkel FS (2014). A new approach for efficient genotype imputation using information from relatives. BMC Genomics. 15: 478. doi: 10.1186/1471-2164-15-478

Seixas L, De Melo CB, Menezes AM, Ramos AF, et al. (2017). Study on environmental indices and heat tolerance tests in hair sheep. Trop. Anim. Health Pro. 49:975-982.

Thom EC (1959). The discomfort index. Weatherwise 12:57-61.

Valtorta E, Scarpati E, Leva R, Gallardo C (2000). Summer Environmental effects on milk production and composition in an Argentine grazing system. In biometeorology and urban climatology at the turn of the millennium. Proceedings of the sixth International Symposium on Biometeorology and Urban Climatology at the Turn of the Millennium. WCASP-50, WMO/TD (Vol. 1026, pp. 371-374).

Van Der Westhuizen RR, Schoeman SJ, Jordan GF, Van WJB (2001). Genetic parameters for reproductive traits in a beef cattle herd estimated using multitrait analysis. Animal Sci. 31:41-48.

Vergara O, Cerón M, Hurtado N, Arboleda E, et al. (2008). Estimación de la heredabilidad del intervalo de partos en bovinos cruzados. Revista MVZ Córdoba. 13: 1192-1196.

Garay ODV, Humanes NM, Murillo JMF, Pérez MH, et al. (2015). Heredabilidades, correlaciones y tendencias genéticas para características reproductivas en una población bovina multirracial en Colombia. CES Medicina Veterinaria Zootecnia. 10: 8-17.

Wasike CB, Indetie D, Ojango JM and Kahi AK (2009). Direct and maternal (co)variance components and genetic parameters for growth and reproductive traits in the Boran cattle in Kenya. Trop. Anim. Health Pro. 41:741-748.

Wiggans GR, VanRaden PM, Cooper TA (2011). The genomic evaluation system in the United States: past, present, future. Dairy Sci. 94: 3202-3211. doi: 10.3168/jds.2010-3866

Yagüe G, Goyache F, Becerra J, Moreno C, et al. (2009). Bayesian estimates of genetic parameters for pre-conception traits, gestation length and calving interval in beef cattle. Animal Reprod. Sci. 114: 72-80. 